American Journal of Animal and Veterinary Sciences 2 (4): 121-126, 2007

ISSN 1557-4555

(C) 2007 Science Publications

\title{
Effects of Azadirachta indica on Sheep Infected Naturally with Helminthes
}

\author{
${ }^{1}$ F.R. Macedo, ${ }^{2}$ H. Louvandini, ${ }^{1}$ G.R. Paludo, ${ }^{1}$ C.M. McManus, ${ }^{1}$ A.D. Porto, \\ ${ }^{1}$ R.F.S. Martins, ${ }^{1}$ P.G. Viana and ${ }^{2}$ B.P. Neves \\ ${ }^{1}$ Faculdade de Agronomia e Medicina Veterinaria, Universidade de Brasília \\ CP 04508, CEP 70910-900, Brasilia, Distrito Federal, Brazil \\ ${ }^{2}$ EMBRAPA Embrapa Arroz e Feijao, Rodovia GO-462, km 12 Zona Rural \\ C.P. 179, 75375-000 Santo Antônio de Goiás, Goiás, Brazil
}

\begin{abstract}
The objective of this study was to evaluate the effects of neem (Azadirachta indica) on natural helminthes infection in lambs. Forty, four-month-old entire Santa Ines lambs were grazed on pasture, over a 20 week period. They were divided into 4 treatments: Without drenching (ND), $3 \mathrm{~g}$ A. indica/animal $\left(\mathrm{A}_{3}\right), 6 \mathrm{~g}$ A. indica/animal $\left(\mathrm{A}_{6}\right)$ and $9 \mathrm{~g}$ A. indica/animal $\left(\mathrm{A}_{9}\right)$ over 5 consecutive days, with an interval of 25 days between drenchings. Faeces were collected weekly and lamb weight and blood collection were carried out fortnightly. Four weeks after the last drenching all lambs were slaughtered, and worm burdens calculated. No significant differences were observed for lamb performance between treatments. Blood parameters highlighted the progress of the worm infections, with sheep on treatments $A_{6}$ and $A_{9}$ ending the experiment showing anemia. There was an increase in the total number of worms associated with increasing levels of neem, especially due to the increase in number of $H$. contortus in detriment to the number of $T$. colubriformis for highest levels of neem $\left(\mathrm{A}_{6}\right.$ and $\left.\mathrm{A}_{9}\right)$. The increasing doses of neem did not improve the control of endoparasites in sheep naturally infected.
\end{abstract}

Key words: Lambs, neem, nematode, ovine, parasite

\section{INTRODUCTION}

Meat consumers are becoming more demanding in terms of product quality. Sheep production systems are therefore looking for technical and economical viable management systems to meet this demand. Products used to control parasite infections in ruminants, in general, leave residues in meat and milk, as well as are eliminated in the faces into the environment. The use of natural products may be an alternative to reduce the use of chemical drugs for the control of parasites. According to Shaalana et al., ${ }^{[1]}$ botanical insecticides are relatively safe and easily degradable in the environment, thereby becoming possible sources of biopesticides.

Neem (Azadirachta indica A. Juss) is a plant from the Meliaceae family, of Asiatic origin, natural of Burma and the arid regions of the Indian sub-continent. It has been indicated for use as a possible alternative phytochemical within the nutritional and sanitary management strategies being used in Brazil. Other species with potential phytochemical pesticide properties include A. Juss, A. excelsa Jack, A. siamens Valeton, Melia azedarach L., Melia toosedan sie and Melia volkensii Gurke ${ }^{[2]}$.

Products obtained from the processing of Indian neem leaves and seeds have been frequently used in this way, especially against ticks, worms and other parasites in cattle and horses ${ }^{[3]}$. An in vitro study carried out by Pessoa $^{[4]}$ showed that $1 \%$ Azadirachtin inhibited the hatching of $68 \%$ of $H$. contortus eggs. Nevertheless there is little information on its use in the field. This study aimed to evaluate the effects of using neem leaves on helminthes in naturally infected sheep.

\section{MATERIALS AND METHODS}

The trial was carried out on the Agua Limpa Farm of the University of Brasilia, with approval from the Animal Care Committee. The climate has a tropical (Aw) Koppen classification. The experiment started in October 2005 and lasted 20 weeks, during the rainy season. Forty entire male, 4-month-old, Santa Ines hair lambs, with an initial mean live weight of $11 \pm 2.73 \mathrm{~kg}$,

Corresponding Author: H. Louvandini, Faculdade de Agronomia e Medicina Veterinária, Universidade de Brasília, CP 04508 CEP 70910900 Brsília, Distrito Federal, Brazil 
were divided in four treatments: without drenching (ND), drenching with $3 \mathrm{~g}$ A. indica/animal ( $\left.\mathrm{A}_{3}\right), 6 \mathrm{~g} A$. indica/animal $\left(\mathrm{A}_{6}\right)$ and $9 \mathrm{~g} A$. indica/animal $\left(\mathrm{A}_{9}\right)$ during five consecutive days with interval of 25 days between drenching and with a total of four drenchings. The leaves of the A. indica were dry, chopped and stored protected of the light, before to offer to the sheep.

The animals were kept together on a 4 hectare Andropogon gayanus pasture, at a density of 10 animals/ha. Once a day they received $150 \mathrm{~g} / \mathrm{animal} / \mathrm{day}$ of the concentrate mixture composed of $30 \%$ soybean meal, 20\% wheat meal, 50\% corn and mineral salt ad libitum. Pasture samples were collected monthly. All feed samples were analysed for dry matter (DM), crude protein (CP), ether extract (EE) and ash (A) using Association of Official Agricultural Chemists ${ }^{[5]}$ procedures and neutral detergent fiber (NDF) and acid detergent fiber (ADF) according to Van Soest et al., ${ }^{[6]}$.

Faeces collection for faecal egg counts (FEC) by the Ueno and Gonçalves ${ }^{[7]}$ method were collected weekly. Lamb weights and blood were collected fortnightly. Blood samples were taken from the jugular vein in vacutainer tubes with EDTA to carry out hemograms. The number of erythrocytes, leukocytes and the concentration of hemoglobin were determined in an automatic cell counter (CC 550-CELM ${ }^{\mathrm{TM}}$, Brazil). The hematocrit was determined using a microcentrifuge. The identification of leukocyte types was carried out by observation of 100 cells in a blood smear stained with Giemsa. Mean corpuscular volume (MCV) and mean corpuscular haemoglobin concentration (MCHC) were obtained by calculation. The blood was centrifuged and the plasma was taken and stored at $-20^{\circ} \mathrm{C}$ for later analysis of total protein (Labtest ${ }$, Brazil). Four weeks after the final drenching all lambs were slaughtered. The abomasum and intestines from each animal were processed to recover the adult worm burden as described by $\mathrm{Cenci}^{[8]}$. The experiment was in a totally random design, with four treatments and ten repetitions. Data were analysed using $\mathrm{SAS}^{[9]}$. Traits measured weekly and fortnightly were analysed as repeated measurements (FEC and hematological parameters) by PROC MIXED. For traits measured a single time (initial $\mathrm{LW}$, final $\mathrm{LW}$, total gain, daily gain and worm count) linear and quadratic regressions were carried out using PROC REG. The FEC and worm count were transformed $(\log x+10)$.

\section{RESULTS AND DISCUSSION}

The means of the chemical analyses (DM, CP, FDN, FDA, EE and A) carried out on the
Table 1: Mean values for live weight (LW), total gain and daily gain in Santa Ines sheep under natural infection with different levels of Azaradactin drenching

\begin{tabular}{llllll}
\hline & \multicolumn{5}{c}{ Azadirachta indica (neem) } \\
Variables & $\begin{array}{l}\text { Not } \\
\text { Drenched }\end{array}$ & $3 \mathrm{~g}$ & $6 \mathrm{~g}$ & $9 \mathrm{~g}$ & Regression \\
\hline LW initial (kg) & 10.8 & 12.6 & 10.6 & 10.6 & NS* \\
LW final (kg) & 25.0 & 27.9 & 23.6 & 26.8 & $\mathrm{NS}$ \\
Total gain (kg) & 14.0 & 14.2 & 13.5 & 15.7 & $\mathrm{NS}$ \\
Daily gain (g/day) & 123 & 124 & 118 & 137 & $\mathrm{NS}$ \\
\hline
\end{tabular}

*NS not significant

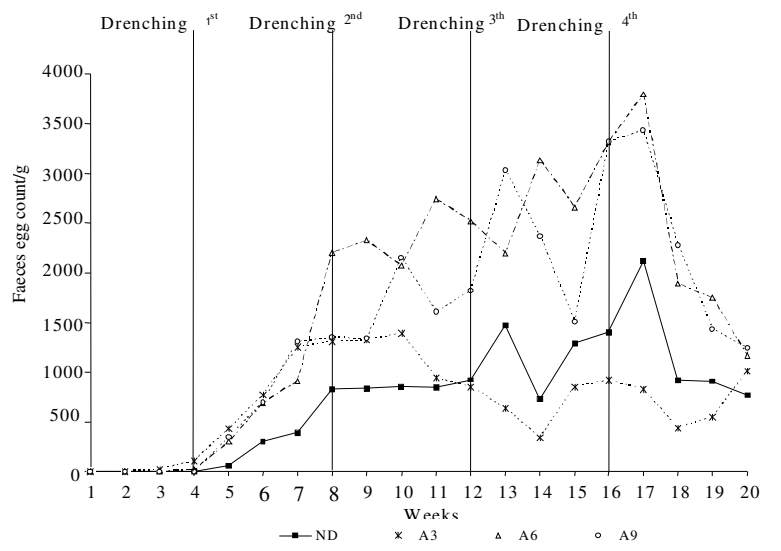

Fig. 1: Faecal egg counts of Santa Ines sheep under natural infection, without drenching (ND), and receiving $\quad 3 \mathrm{~g} A$. indica/animal $\left(\mathrm{A}_{3}\right), 6 \mathrm{~g}$ A. indica/animal $\left(\mathrm{A}_{6}\right)$ and $9 \mathrm{~g}$ A. indica/animal $\left(\mathrm{A}_{9}\right)$ during five days with four weeks intervals

Andropogon gayanus grass were 315, 115, 668, 334, 29 and $47 \mathrm{~g} \mathrm{~kg}^{-1} \mathrm{DM}$ and concentrate mixture were 874 , $158,129,56,41$ and $23 \mathrm{~g} \mathrm{~kg}^{-1} \mathrm{DM}$, respectively.

Production performance data of the sheep are shown in Table 1. No significant differences $(\mathrm{p}>0.05)$ were found between neem treatments for the traits evaluated (initial and final live weight, total gain and daily gain).

Only sheep on treatment $A_{3}$ showed FEC values lower than the control (ND) from the $12^{\text {th }}$ week (Fig. 1), but differences were not significant $(\mathrm{p}>0.05)$. In weeks 11 to 14 , groups ND and $\mathrm{A}_{3}$ showed a lower egg count than for the $A_{6}$ and $A_{9}$ treatments $(p<0.10)$. No other significant differences were noted. A positive linear regression was found when increasing levels of Neem were plotted against overall FEC $\left(\mathrm{y}=133 \mathrm{X}+747, \mathrm{R}^{2}=\right.$ $0.15, \mathrm{p}=0.016)$.

Data for red cell and total plasma protein are in Table 2. There was a progressive reduction in the hematocrit, number of erythrocytes and hemoglobin along the experiment, associated with the evolution of the infection in all treatments. Below normal and more 
American J. Animal \& Vety. Sci., 2 (4): 121-126, 2007

Table 2: Mean hematocrit, erythrocytic and hemoglobin values, mean corpuscular volume (MCV), mean corpuscular hemoglobin concentration (MCHC) and total protein findings in Santa Ines sheep under natural infection with different levels of Azaradactin drenching

\begin{tabular}{|c|c|c|c|c|c|c|c|c|c|}
\hline \multirow[t]{2}{*}{ Parameters } & \multirow[t]{2}{*}{ Treat. $^{1}$} & \multicolumn{8}{|l|}{ Weeks } \\
\hline & & 5 & 7 & 9 & 11 & 13 & 15 & 17 & 19 \\
\hline \multirow[t]{4}{*}{ Hematocrit \% $(27-45)^{*}$} & ND & 37.0 & 33.0 & 30.0 & $30.3^{\mathrm{ab}}$ & $28.5^{\mathrm{ab}}$ & $27.2^{\mathrm{ab}}$ & $26.0^{b}$ & $28.9^{\mathrm{ab}}$ \\
\hline & $\mathrm{A}_{3}$ & 37.3 & 30.4 & 27.8 & $33.6^{\mathrm{b}}$ & $29.3^{\mathrm{b}}$ & $28.3^{\mathrm{b}}$ & $28.6^{\mathrm{b}}$ & $30.8^{\mathrm{b}}$ \\
\hline & $\mathrm{A}_{6}$ & 36.1 & 30.6 & 28.3 & $29.3^{\mathrm{a}}$ & $24.9^{\mathrm{a}}$ & $25.0^{\mathrm{a}}$ & $21.9^{\mathrm{a}}$ & $26.9^{\mathrm{a}}$ \\
\hline & $\mathrm{A}_{9}$ & 36.3 & 30.0 & 28.2 & $31.2^{\mathrm{ab}}$ & $26.0^{\mathrm{ab}}$ & $26.5^{\mathrm{ab}}$ & $25.9^{\mathrm{b}}$ & $26.7^{\mathrm{a}}$ \\
\hline \multirow[t]{4}{*}{ Erythrocytes $\times 10^{6} / \mu \mathrm{L}\left(9-15 \times 10^{6}\right)^{*}$} & ND & $13.2^{\mathrm{a}}$ & $11.5^{\mathrm{c}}$ & 9.1 & $9.5^{\mathrm{ab}}$ & $7.9^{\mathrm{b}}$ & 8.7 & $8.4^{\mathrm{c}}$ & $9.9^{\mathrm{ab}}$ \\
\hline & $\mathrm{A}_{3}$ & $14.6^{\mathrm{ab}}$ & $10.2^{\mathrm{ab}}$ & 8.2 & $9.9^{\mathrm{b}}$ & $7.6^{\mathrm{b}}$ & 9.3 & $8.3^{\mathrm{c}}$ & $10.6^{\mathrm{b}}$ \\
\hline & $\mathrm{A}_{6}$ & $14.9^{\mathrm{b}}$ & $11.1^{\mathrm{bc}}$ & 8.1 & $8.5^{\mathrm{a}}$ & $6.2^{\mathrm{a}}$ & 8.7 & $5.8^{\mathrm{a}}$ & $8.7^{\mathrm{a}}$ \\
\hline & $\mathrm{A}_{9}$ & $13.0^{\mathrm{a}}$ & $9.9^{\mathrm{a}}$ & 8.7 & $9.2^{\mathrm{ab}}$ & $6.6^{\mathrm{ab}}$ & 9.8 & $6.9^{\mathrm{b}}$ & $8.8^{\mathrm{a}}$ \\
\hline \multirow[t]{4}{*}{ Hemoglobin $(\mathrm{g} / 100 \mathrm{~mL})(9-15)^{*}$} & ND & 9.9 & $9.8^{\mathrm{b}}$ & $9.4^{\mathrm{b}}$ & $9.2^{\mathrm{ab}}$ & $6.9^{\mathrm{ab}}$ & $6.7^{\mathrm{b}}$ & $8.2^{\mathrm{b}}$ & $9.2^{\mathrm{b}}$ \\
\hline & $\mathrm{A}_{3}$ & 9.3 & $9.0^{\mathrm{ab}}$ & $8.3^{\mathrm{a}}$ & $9.6^{\mathrm{b}}$ & $7.3^{\mathrm{b}}$ & $6.4^{\mathrm{b}}$ & $8.5^{\mathrm{b}}$ & $9.7^{\mathrm{b}}$ \\
\hline & $\mathrm{A}_{6}$ & 9.5 & $8.9^{\mathrm{a}}$ & $8.0^{\mathrm{a}}$ & $8.4^{\mathrm{a}}$ & $6.4^{\mathrm{ab}}$ & $6.1^{\mathrm{a}}$ & $6.2^{\mathrm{a}}$ & $8.5^{\mathrm{ab}}$ \\
\hline & $\mathrm{A}_{9}$ & 9.3 & $8.8^{\mathrm{a}}$ & $8.2^{\mathrm{a}}$ & $8.7^{\mathrm{ab}}$ & $6.3^{\mathrm{a}}$ & $6.3^{\mathrm{a}}$ & $7.1^{\mathrm{ab}}$ & $7.9^{\mathrm{a}}$ \\
\hline \multirow[t]{4}{*}{$\operatorname{MCV}(f L)(28-40)^{*}$} & ND & $29.3^{\mathrm{a}}$ & $28.7^{\mathrm{a}}$ & $33.0^{\mathrm{ab}}$ & 32.8 & $36.7^{\mathrm{a}}$ & 31.4 & $31.8^{\mathrm{a}}$ & 29.1 \\
\hline & $\mathrm{A}_{3}$ & $31.3^{\mathrm{b}}$ & $29.7^{\mathrm{ab}}$ & $33.8^{\mathrm{ab}}$ & 33.8 & $38.6^{\mathrm{ab}}$ & 30.7 & $34.7^{\mathrm{ab}}$ & 29.3 \\
\hline & $\mathrm{A}_{6}$ & $31.1^{\mathrm{b}}$ & $27.9^{\mathrm{ab}}$ & $35.5^{\mathrm{b}}$ & 34.8 & $41.0^{\mathrm{b}}$ & 30.1 & $38.6^{\mathrm{c}}$ & 31.4 \\
\hline & $A_{9}$ & $30.5^{\mathrm{ab}}$ & $30.1^{\mathrm{b}}$ & $32.7^{\mathrm{a}}$ & 34.7 & $41.7^{b}$ & 27.7 & $37.6^{\mathrm{bc}}$ & 30.5 \\
\hline \multirow[t]{4}{*}{$\operatorname{MCHC}(\%)(31-34)^{*}$} & ND & 27.0 & 29.5 & $31.3^{\mathrm{b}}$ & $31.3^{\mathrm{b}}$ & 24.8 & 22.8 & $31.2^{\mathrm{b}}$ & 32.2 \\
\hline & $\mathrm{A}_{3}$ & 25.54 & 29.8 & 28.9 & $28.7^{\mathrm{a}}$ & 25.5 & 23.7 & $29.4^{\mathrm{ab}}$ & 31.6 \\
\hline & $\mathrm{A}_{6}$ & 26.3 & 29.0 & $28.1^{\mathrm{a}}$ & $28.7^{\mathrm{a}}$ & 25.5 & 24.3 & $29.0^{\mathrm{ab}}$ & 32.0 \\
\hline & $\mathrm{A}_{9}$ & 25.6 & 29.5 & 28.7 & $27.8^{\mathrm{a}}$ & 23.9 & 23.4 & $28.6^{\mathrm{a}}$ & 31.2 \\
\hline \multirow[t]{4}{*}{ Total Protein $(\mathrm{g} / 100 \mathrm{~mL})(6,0-7,5)^{*}$} & ND & 6.8 & $6.6^{\mathrm{b}}$ & 6.5 & $6.5^{\mathrm{a}}$ & 6.4 & $6.7^{\mathrm{ab}}$ & $6.4^{\mathrm{ab}}$ & $6.9^{\mathrm{b}}$ \\
\hline & $\mathrm{A}_{3}$ & 6.8 & $6.4^{\mathrm{ab}}$ & 6.5 & $6.9^{\mathrm{b}}$ & 6.5 & $6.8^{\mathrm{b}}$ & $6.6^{\mathrm{b}}$ & $6.9^{\mathrm{b}}$ \\
\hline & $\mathrm{A}_{6}$ & 6.7 & $6.3^{\mathrm{a}}$ & 6.3 & $6.5^{\mathrm{a}}$ & 6.1 & $6.3^{\mathrm{ab}}$ & $5.9^{\mathrm{a}}$ & $6.6^{\mathrm{a}}$ \\
\hline & $\mathrm{A}_{9}$ & 6.6 & $6.6^{\mathrm{b}}$ & 6.4 & $6.9^{\mathrm{b}}$ & 6.3 & $6.2^{\mathrm{a}}$ & $6.2^{\mathrm{ab}}$ & $6.7^{\mathrm{a}}$ \\
\hline
\end{tabular}

${ }^{1} \mathrm{ND}$ (not drenched), $\mathrm{A}_{3}\left(3 \mathrm{~g} A\right.$. indica/animal), $\mathrm{A}_{6}\left(6 \mathrm{~g} A\right.$. indica/animal) and $\mathrm{A}_{9}\left(9 \mathrm{~g} A\right.$. indica/animal). * Reference values from Jain, (1993). ${ }^{\mathrm{a}, \mathrm{b}, \mathrm{c}}$ Mean followed by different letters in the same column are significantly different $(\mathrm{P} \leq 0.05)$

Table 3: Mean leukocytic values findings in Santa Ines sheep under natural infection with different levels of Azaradactin drenching

\begin{tabular}{|c|c|c|c|c|c|}
\hline \multirow[t]{2}{*}{ Parameters } & \multirow[t]{2}{*}{ Treatments $^{1}$} & \multicolumn{4}{|l|}{ Weeks } \\
\hline & & 5 & 9 & 13 & 19 \\
\hline \multirow[t]{4}{*}{ Leukocytes/ $\mu \mathrm{L}(4,000-12,000)^{*}$} & No Drenched & $11,300^{b}$ & 10,500 & $8,500^{\mathrm{a}}$ & 12,100 \\
\hline & $3 \mathrm{~g}$ & $9,600^{\mathrm{ab}}$ & 9,500 & $9,300^{\mathrm{ab}}$ & 12,200 \\
\hline & $6 \mathrm{~g}$ & $10,600^{\mathrm{ab}}$ & 10,000 & $8,900^{\mathrm{a}}$ & 10,900 \\
\hline & $9 \mathrm{~g}$ & $9,000^{\mathrm{a}}$ & 10,700 & $11,000^{\mathrm{b}}$ & 11,600 \\
\hline \multirow[t]{4}{*}{ Monocyte $/ \mu \mathrm{L}(0-750)^{*}$} & No Drenched & $709^{\mathrm{b}}$ & 257 & 463 & $382^{\mathrm{ab}}$ \\
\hline & $3 \mathrm{~g}$ & $308^{\mathrm{a}}$ & 205 & 271 & $587^{\mathrm{b}}$ \\
\hline & $6 \mathrm{~g}$ & $296^{\mathrm{a}}$ & 371 & 293 & $223^{\mathrm{a}}$ \\
\hline & $9 \mathrm{~g}$ & $506^{\mathrm{ab}}$ & 272 & 250 & $338^{\mathrm{a}}$ \\
\hline \multirow[t]{4}{*}{ Lymphocyte/ $\mu \mathrm{L}(2,000-9,000)^{*}$} & No Drenched & $5,378^{\text {bc }}$ & 3,743 & 3,539 & 5,591 \\
\hline & $3 \mathrm{~g}$ & $3,881^{\mathrm{a}}$ & 4,108 & 4,739 & 5,459 \\
\hline & $6 \mathrm{~g}$ & $5,780^{c}$ & 4,220 & 4,537 & 4,502 \\
\hline & $9 \mathrm{~g}$ & $4,498^{\mathrm{ab}}$ & 4,673 & 4,779 & 4,786 \\
\hline \multirow[t]{4}{*}{ Neutrophil/ $\mu \mathrm{L}(700-6,000)^{*}$} & No Drenched & 5,339 & $6,018^{\mathrm{b}}$ & 3,327 & 5,474 \\
\hline & $3 \mathrm{~g}$ & 5,078 & $3,851^{\mathrm{a}}$ & 3,006 & 5,285 \\
\hline & $6 \mathrm{~g}$ & 4,393 & $5,591^{\mathrm{b}}$ & 4,199 & 5,628 \\
\hline & $9 \mathrm{~g}$ & 5,390 & $5,629^{\mathrm{b}}$ & 5,781 & 4,125 \\
\hline \multirow[t]{4}{*}{ Eosinophil/ $\mu \mathrm{L}(0-1,000)^{*}$} & No Drenched & $308^{\mathrm{b}}$ & $844^{\mathrm{ab}}$ & $619^{\mathrm{a}}$ & 703 \\
\hline & $3 \mathrm{~g}$ & $195^{\mathrm{ab}}$ & $823^{\mathrm{ab}}$ & $822^{\mathrm{a}}$ & 521 \\
\hline & $6 \mathrm{~g}$ & $287^{\mathrm{ab}}$ & $600^{\mathrm{a}}$ & $1,023^{\mathrm{a}}$ & 586 \\
\hline & $9 \mathrm{~g}$ & $132^{\mathrm{a}}$ & $1475^{\mathrm{b}}$ & $2,346^{\mathrm{b}}$ & 750 \\
\hline \multirow[t]{4}{*}{ Basophil/ $\mu \mathrm{L}(0-300)^{*}$} & No Drenched & 56 & 22 & 33 & 87 \\
\hline & $3 \mathrm{~g}$ & 38 & 35 & 61 & 109 \\
\hline & $6 \mathrm{~g}$ & 49 & 22 & 58 & 76 \\
\hline & $9 \mathrm{~g}$ & 34 & 0 & 33 & 70 \\
\hline
\end{tabular}

${ }_{\mathrm{T}}^{\mathrm{N} D}$ (no drenched), $\mathrm{A}_{3}(3 \mathrm{~g} A$. indica/animal $), \mathrm{A}_{6}\left(6 \mathrm{~g}\right.$ A. indica/animal) and $\mathrm{A}_{9}(9 \mathrm{~g} A$. indica
Mean followed by different letters in the same column are significantly different $(\mathrm{p} \leq 0.05)$.

significant values for these traits were seen from the 13th week on which coincides with the third development cycle of adult worms. Values for total protein were within normal ranges. In general, these parameters were higher for the ND and $\mathrm{A}_{3}$ treatments than $\mathrm{A}_{6} \quad \mathrm{e} \mathrm{A}_{9}$ in the last four weeks. This was associated with a lower infection with $H$. contortus and higher predominance of $T$. colubriformis.
The white cell analyses are in Table 3, with values within normal values for most of them. There was a progressive increase in the number of eosinophils with the advance of parasite infection in all treatments, with higher than normal values for treatment $\mathrm{A}_{6}\left(13^{\text {th }}\right.$ week $)$ and $A_{9}\left(9^{\text {th }}\right.$ and $13^{\text {th }}$ weeks).

The adult worm results are shown in Table 4. Predominant species were T. colubriformis and 
American J. Animal \& Vety. Sci., 2 (4): 121-126, 2007

Table 4: Number of worms per species and sex in Santa Ines sheep under natural infection with different levels of Azaradactin drenching

\begin{tabular}{|c|c|c|c|c|c|}
\hline \multirow[b]{2}{*}{ Species } & \multirow[b]{2}{*}{ No Drenched } & \multicolumn{3}{|c|}{ Azadirachta indica (neem) } & \multirow[b]{2}{*}{ Regression } \\
\hline & & $3 \mathrm{~g}$ & $6 \mathrm{~g}$ & $9 \mathrm{~g}$ & \\
\hline Total geral & 3539 & 5356 & 4855 & 6353 & $Y=525.81 X+517.55$ \\
\hline Female: male & 2093: 1286 & 2679: 2387 & 2554: 2301 & 3538: 2815 & $\mathrm{R}^{2}=0.31 \mathrm{P}=0.0009$ \\
\hline T. colubriformis & $2822(79.74)^{*}$ & $4099(73.53)$ & $1966(40.51)$ & $1436(22.60)$ & $\mathrm{NS}^{1}$ \\
\hline Female: male & $(1642: 1180)$ & $2264: 1835$ & $1089: 878$ & $797: 639$ & \\
\hline H. contortus & $439^{\mathrm{a}}(12.40)$ & $979(18.27)$ & $2619(53.93)$ & 4647 (73.14) & $Y=474 X+56.74$ \\
\hline Female: male & $289: 150$ & $533: 446$ & $1306: 1313$ & $2566: 2081$ & $\mathrm{R}^{2}=0.28 \mathrm{P}=0.0011$ \\
\hline O. columbianum & $248(7.0)$ & $214(3.9)$ & $230(4.73)$ & $223(3.51)$ & NS \\
\hline Female: male & $152: 96$ & $115: 99$ & $124: 106$ & $134: 89$ & \\
\hline Cooperia $s p$ & $7(0.19)$ & $3(0.05)$ & 0 & 0 & NS \\
\hline Female: male & $7: 0$ & $3: 0$ & $0: 0$ & $0: 0$ & \\
\hline S. papillosus & $16(0.45)$ & $38(0.7)$ & $28(0.57)$ & $5(0.07)$ & NS \\
\hline T. globulosa & $5(0.14)$ & $19(0.35)$ & $6(0.12)$ & $9(0.14)$ & NS \\
\hline Female: male & $3: 2$ & $12: 7$ & $2: 4$ & $3: 6$ & \\
\hline M. expansa & $2(0.056)$ & $4(0.07)$ & $5(0.10)$ & $33(0.52)$ & NS \\
\hline
\end{tabular}

*\% total geral species as reference. ${ }^{1}$ Not significant

$H$. contortus, the sum of these being higher than $92 \%$ of the total worm count over all treatments. For the total count a positive linear regression was found with increasing levels of neem in the treatments $(\mathrm{Y}=525.81 \mathrm{X}+517.55, \mathrm{R}=0.31, \mathrm{P}=0.0009)$. This was mainly influenced by a positive linear regression for number of $H$. contortus $(\mathrm{Y}=474 \mathrm{X}+56.74, \mathrm{R}=0.28, \mathrm{P}$ $=0.00011)$. Although there was a numerical decrease for $T$. colubriformis as neem level rose, the negative regression $(\mathrm{Y}=-20 \mathrm{X}+347, \mathrm{R}=0.06)$ was not significant $(\mathrm{P}=0.1667)$. Nevertheless the proportion of the T. colubriformis population decreased from $74 \%$ in treatment ND to $22.60 \%$ in treatment $\mathrm{A}_{9}$. The inverse was seen with $H$. contortus which was $12.40 \%$ in treatment ND and rose to $73.14 \%$ in treatment $\mathrm{A}_{9}$. No other worm species showed treatment effects in this experiment.

Increasing levels of neem $(0,3,6$ and $9 \mathrm{~g}$ leaves/animal/5 consecutive days with a 25 day interval over 5 months), did not result in a lower infection of endoparasites in sheep at pasture. Only treatment $\mathrm{A}_{3}$ FEC values were below the control, but no significant differences were noted. This group was clinically characterized as having a light infection with FEC values below 1,000 FEC, after the $12^{\text {th }}$ week. The $\mathrm{A}_{6}$ and $\mathrm{A}_{9}$ treatments showed a severe infection from the $10^{\text {th }}$ week, with FEC values above 2,000, and highest values being 3,976 and 3,433 in the $17^{\text {th }}$ week, respectively. These two treatments $\left(\mathrm{A}_{6}\right.$ and $\left.\mathrm{A}_{9}\right)$ showed a predominance of Haemonchus, whose females produce a higher number of eggs than T. colubriformis ${ }^{[7]}$.

Although in mice neem leaf extracts were shown to be hematostimulatory and immunostimulatory $\left.{ }^{[10}\right]$, the same effects were not found in this experiment, where the parasite infection did not decrease with the addition of the leaves. The leukocyte count did not change and there was a discrete eosinophilia. It is important to note that there was a greater reduction in the hematocrit and number of red blood cells in the $13^{\text {th }}, 15^{\text {th }}$ and $17^{\text {th }}$ weeks, when the higher infections were noted. This was probably due to the complete development of three or four parasite cycles as the cycle for the worms found is generally 4 weeks/cycle. This was reflected by the high blood loss caused by these parasites. During this period all animals showed normocytic-hypochromic anemia, which happens in cases of transitional phase from acute to chronic blood loss in which iron deficiency is setting in with a reduction of erythropoiesis caused by intense parasitism ${ }^{[1]}$. In the $19^{\text {th }}$ week the hematocrit and number of erythrocytes returned to within normal reference values, with higher total protein in the plasma for treatments ND and $A_{3}$, probably due to the predominance of $T$. colubriformis in these treatments. This is a less pathogenic species than $H$. contortus (hematophage), which was predominant in treatments $\mathrm{A}_{6}$ and $\mathrm{A}_{9}$, and whose animals still showed anemia at this stage, but no differences on animal performance was observed between treatments suggesting resilience despite of the more pathogenic infection found.

Haque et al., ${ }^{[10]}$ did not observe any signs of toxicity using preparations of neem leaf extracts (NLP1 unit) once weekly for four weeks in mice, as indicated by hepatic enzymes and histopathological exams. Intoxication is associated with the use of a high number of leaves of the plant $(100 \mathrm{~g} / \mathrm{animal} / \mathrm{day})$ as an integral part of the diet of sheep ${ }^{[12]}$. In the present study, the doses used were lower than this value and although no specific toxicity tests were carried out, the growth and blood parameters of these animals did not indicate that higher neem levels had been hepatotoxic or debilitating 
for the sheep which could have justified the higher infection level in treatment $\mathrm{A}_{9}$.

The quality of the infection changed with increasing levels of neem administrated $\left(\mathrm{A}_{6}\right.$ and $\left.\mathrm{A}_{9}\right)$. There was a greater development of $H$. contortus, which is pathologically more serious than that of $T$. colubriformis. Considering the ND treatment, the proportion of these two species was $79.74 \%$ and $12.40 \%$ for $T$. colubriformis and $H$. contortus respectively, but as the neem level rose the T. colubriformis population fell to $22.60 \%$ and the $H$. contortus rose to $73.14 \%$ in treatment $\mathrm{A}_{9}$ at the end of the trial (week 20). Given the complexity of factors involved in a mixed natural infection it is difficult to discover what is happening. The neem could be interfering in the gastrointestinal tract environment, affecting the motility (laxative), microbiotics, improving the availability of certain nutrients, among others and thereby promoting the development of a certain species in detriment of the other. There are studies with tannin rich plants which show that the $\mathrm{pH}$ of the gastrointestinal tract interferes in the mode of action of these substances ${ }^{[13]}$. This may be happening with the neem as these two worm species inhabit distinct portions of the gastrointestinal tract. The $H$. contortus develops in the abomasum (acid $\mathrm{pH}$ ) while $T$. colubriformis develops in the small intestine (alkaline $\mathrm{pH}$ ). All these questions are speculative and need to be further investigated.

Hordegen et al. ${ }^{[14]}$ did not observe any action on parasites of neem seed extract at $3 \mathrm{mg} \mathrm{kg}^{-1}$ live weight in sheep artificially infected with $H$. contortus and $T$. colubriformis. Costa et al. ${ }^{[15]}$ evaluated the daily use of neem leaves in the concentrate of sheep at $0.1 \mathrm{~g}$ leaves $/ \mathrm{kg} \mathrm{LW}$ and $0.2 \mathrm{~g}$ leaves $/ \mathrm{kg} \mathrm{LW}$ to control endoparasites over a three months period. They also concluded that neem was not efficient as to control worm loads.

In plant studies it is important to note that the plant part, quantity utilized should be clearly defined. In published studies all of this information is not always available, which makes comparison between studies more difficult. According to Martinez ${ }^{[16]}$, as well as azadiractina, which is considered the most potent limonoid present in neem, there are other substances in this plant which may interact or interfere with its action on parasites ${ }^{[17]}$.

New studies should be carried out with this plant with controlled infections, to attempt to decipher the mode of action, as it is still too early to draw any conclusions about this plant as to its use in parasite control. Its action in increasing resilience of the host animal to the worm infection should not de discarded.

\section{ACKNOWLEDGMENTS}

We would like to thank a Finatec for financial support, Nutron ${ }^{\circledR}$ for mineral salt mixture, as well as Madalena Maria Saldanha Coelho for laboratory support.

\section{REFERENCES}

1. Shaalana, E.A.S., D. Canyonb, M.W.F Younesc, A. Hoda and A. Mansoura, 2005. A review of botanical phytochemicals with mosquitocidal potential. Environ. Int., 31: 1149-1166.

2. Mulla M.S. and T. Su, 1999. Activity and biological effects of neem products against arthropods of medical and veterinary importance. J. Am. Mosquito Control Associat., 15: 133-52.

3. Neves, B.P., I.P. Oliveira and J.C.M. Nogueira, 2003. Cultivar e Utilização do Nim Indiano. Circular Técnica/EMPRAPA. 62.

4. Pessoa, L.M., 2001. Atividade ovicida in vitro de plantas medicinais contra Haemonchus contortus. Dissertação (Mestrado em Ciências Veterinárias). Faculdade de Medicina Veterinária, Universidade Estadual do Ceara, Fortaleza, pp: 68.

5. Association of Official Agricultural Chemists, 1995. Official methods of analysis of the AOAC. 16.ed. Arlington: AOAC International, 1: 4/1-4/30.

6. Van Soest, P.J., J.B. Robertson and B.A. Lewis, 1991. Methods for dietary fiber, neutral detergent fiber and nonstarch polyssccharides in ration to animal nutrition. J. Dairy Sci. 74: 3583-3597.

7. Ueno, H. and P.C. Gonçalves, 1998. Manual para diagnósticos das helmintoses de ruminantes, fourth ed., Press Color, pp: 143.

8. Cenci, F.B., H. Louvandini, C. McManus, A. Dell'Porto, D.M. Costa, S.C. Araujo, A.P. Minho and A.L. Abdalla, 2007. Effects of condensed tannin from Acacia mearnsii on sheep infected naturally with gastrointestinal helminthes. Veterinary Parasitology, 144: 132-137.

9. SAS Institute, 2000. The SAS system for Windows, release 8.01. Cary.

10. Haque, E., I. Mandal, S. Pal and R. Baral, 2006. Propylatic dose of neem (Azaridachta indica) leaf preparation restricting murine tumor growth is nontoxic, hematostimulatory and immunostimulatory. Immunopharmacol. Immunotoxicol. 28: 33-50

11. Jain, N.C, 1993. In: Essentials of Veterinary Hematology. 1 Edn., Lea and Febiger, Philadelphia, pp: 417. 
12. Ali, B.H. and A.M.M. Salih, 1982. Suspected Azadirachta indica toxicity in a sheep (correspondence). Vet. Record, 111: 494.

13. Kahiya C., S. Mukaratirwa and S.M. Thamsborg, 2003. Effects of Acacia nilotica and Acacia karoo diets on Haemonchus contortus infection in goats. Vet. Parasitology, 115: 265-274

14. Hordegen P., H. Hertzberg, J. Heilmann, W. Langhans and V. Maurer, 2003. The anthelmintic efficacy of five plant products against gastrointestinal trichostrongylids in artificially infected lambs. Vet. Parasitology, 117: 51-60.
15. Costa, C.T.C., C.M.L. Bevilaqua, M.V. Maciel, A.L.F. Camurca-Vasconcelos, S.M. Morais, M.V.B. Monteiro, V.M. Farias, M.V. da Silv and M.M.C. Souza. Anthelmintic activity of Azadirachta indica A. Juss against sheep gastrointestinal nematodes. Vet. Parasitol. 137: 306-310.

16. Martinez, S.S., 2002. O NIM- Azadirachta indica: natureza, uso múltiplos, produção. Londrina, IAPAR- Instituto Agronômico do Paraná, pp: 124.

17. Schmutterer, H., 1990. Properties and potential of natural pesticides from the neem tree. Azaliracha indica. Ann. Rev. Entomol. 35: 271-297. 